\title{
GCU
}

Glasgow Caledonian

University

University for the Common Good

\section{Teaching sustainability: complexity and compromises}

Anastasiadis, Stephanos; Perkiss, Stephanie; Dean, Bonnie A.; Bayerlein, Leopold; Gonzalez-Perez, Maria Alejandra; Wersun, Alec; Acosta, Pilar; Jun, Hannah; Gibbons, Belinda

Published in:

Journal of Applied Research in Higher Education

DOI:

10.1108/JARHE-02-2020-0029

Publication date:

2021

Document Version

Author accepted manuscript

Link to publication in ResearchOnline

Citation for published version (Harvard):

Anastasiadis, S, Perkiss, S, Dean, BA, Bayerlein, L, Gonzalez-Perez, MA, Wersun, A, Acosta, P, Jun, H \& Gibbons, B 2021, 'Teaching sustainability: complexity and compromises', Journal of Applied Research in Higher Education, vol. 13, no. 1, pp. 272-286. https://doi.org/10.1108/JARHE-02-2020-0029

\section{General rights}

Copyright and moral rights for the publications made accessible in the public portal are retained by the authors and/or other copyright owners and it is a condition of accessing publications that users recognise and abide by the legal requirements associated with these rights.

Take down policy

If you believe that this document breaches copyright please view our takedown policy at https://edshare.gcu.ac.uk/id/eprint/5179 for details of how to contact us. 


\section{Journal of Applied Research in Higher Edu}

\section{Teaching sustainability: Complexity and compromises}

\begin{tabular}{|r|l|}
\hline Journal: & Journal of Applied Research in Higher Education \\
\hline Manuscript ID & JARHE-02-2020-0029.R1 \\
\hline Manuscript Type: & Research Paper \\
\hline Keywords: & educator perception, higher education, sustainability education, WikiRate \\
\hline \multicolumn{2}{|r}{} \\
\hline
\end{tabular}

\section{SCHOLARONE ${ }^{\text {M }}$ \\ Manuscripts}




\title{
Teaching sustainability: Complexity and compromises
}

\begin{abstract}
Purpose: Sustainability is one of the leading challenges of our age, and higher education plays a vital role in supporting the implementation of sustainability initiatives. There has been substantial progress in business schools introducing sustainability into courses with extant literature detailing case studies of sustainability education and student perceptions of their learning. The purpose of this paper is to address the gap in literature from educators' perspectives on their experiences of introducing sustainability teaching using specific teaching tools for sustainability.

Design/methodology/approach: This paper presents a case study on a sustainability teaching tool, WikiRate, that was embedded into business and management courses at seven higher education institutions from across the globe. Interviews were conducted after course delivery to gain insights into the practical challenges of designing and implementing a sustainability education activity.

Findings: The findings show that educators perceive sustainability as a complex issue, presenting a challenge to teaching in university systems whose normative curricula are rooted in instrumental problem-solving. Further, educators described challenges to their own learning in order to implement sustainability into curricula including the need for compromises and adaptions.

Originality/value: This empirical study reports on educators' experiences embedding sustainability into their courses through an innovative teaching tool, WikiRate. This paper has implications for reframing how we can approach sustainability education and presents discussion ways to teach complexity without reduction or simplification.
\end{abstract}

Keywords; educator perception; higher education; sustainability education; WikiRate Article classification: research paper 


\section{Introduction}

Sustainability is widely recognized as one of the leading challenges of our age. In many countries across the world, stakeholders are urging organizations to act purposefully and commit to actions that achieve sustainable solutions to environmental and human challenges (Reade et al., 2008). Demand for sustainable funds has increased to the point where sustainability investing is now "common practice" (Doyle, 2018, p. 6). Companies have reacted by increasingly integrating sustainability into their operations to minimize the impacts of legacy practices (Seager et al., 2013; Lozana, 2018). Governments, too, are moving to integrate sustainability considerations into procurement and investment decisions (see, e.g., European Commission, 2019). In short, a societal transition towards greater sustainability is underway. However, companies are not always doing their share of the work. Even with clear evidence of the sustainability challenges, accompanied by strong community pressure for change, acceptance of the sustainability agenda in business is far from universal, with numerous companies yet to take substantial action (Starik et al., 2013). This hesitation is partly due to the education future business leaders receive.

Higher education plays a vital role in supporting the implementation of sustainability initiatives in business, as well as the creation and use of sustainability reporting by companies and stakeholders, respectively. Business and management schools (hereafter: business schools) have been criticized for not meeting societal demands in relation to key graduate qualities such as ethics, leadership, corporate social responsibility (CSR), cultural awareness, cultural intelligence and sustainability (Persons, 2012; Tekarslan and Erden, 2014). Ghoshal (2005) provides a trenchant critique of business schools' tendency to elide questions of moral responsibility in their teaching. Wang et al. (2011) show a clear link between business school education and a culture of greed. Business schools have typically tried to address sustainabilityrelevant criticisms by embedding sustainability in their educational practices, an exigency that has become more salient over time. The past decade has thus seen substantial formal progress in this regard, with most business schools having introduced at least one course dedicated to sustainability (Parris and McInnes-Bowers, 2017). One way that they have done so is through adoption of, and engagement with, the Principles for Responsible Management Education (PRME), which were developed in 2007 as a global principle-based platform (United Nations (UN) PRME, n.d.).

However, the sustainability strategies that underpin principles such as PRME are not always well aligned with educational practice (Snelson-Powell et al., 2016). Some business schools, particularly those within larger and more elite institutions, decouple their espoused commitments from their practices (Snelson-Powell et al., 2016). This may at least partly explain the observation that sustainability education frequently occurs in, "inset boxes in disciplinary texts or elective courses" (Parris and McInnes-Bowers, 2017, p. 692). That is, sustainability is not always embedded in mainstream business education, meaning that 'what we say we're going to do' and 'what we actually do' are not always aligned. 
Higher education is also seeing increasing examples of courses that aim to develop socially conscious practitioners through a focus on business not as usual (Parris and McInnes-Bowers, 2017). Such educational initiatives are congruent with a trend in business to integrate CSR and sustainability into the core structures of an organisation (see Dumay et al., 2016 and Bebbington and Unerman, 2018, for examples). Numerous studies have published university students' understanding, perceptions, knowledge and attitudes of sustainable development (e.g., Cebrian and Junyent, 2015). The management education literature is littered with case studies of student transformation - in self-confidence, skills or knowledge - resulting from educational interventions that embed sustainability into curricula (see Figueiro and Raufflet, 2015). These case studies usually include active participation or real-world linkages to facilitate deeper and more meaningful student learning, and a consequent change in students' perceptions, skills and knowledge. The available literature suggests that sustainability-related activities, programs or initiatives are generally successful.

However, from the way case studies are presented in the management education literature, the reader could easily infer that designing and implementing a sustainability intervention is straightforward. What is missing from the literature is educators' perspectives, stories of experience around introducing sustainability teaching and using specific teaching tools for sustainability, within the constraints of existing tertiary course structures. This paper starts to address the gap by offering insights into the practical challenges of designing and implementing a sustainability education activity. In doing so, it contributes to the higher education literature in several ways. It presents a new pedagogical tool, WikiRate, for sustainability education (see "Tools and approaches" section, below). Using this tool, the paper outlines challenges, complexities, and lessons learnt associated with sustainability education from an educator's perspective. That is useful for educators aiming to embark on sustainability teaching in their own business and management courses. The paper also addresses some of the wider issues around the use of sustainability teaching tools, which educators will be able to use to inform their own teaching. The remainder of the paper proceeds as follows. The next section is a brief literature review on the complexities of sustainability teaching. An outline of the sustainability tool and of the case study method used then follow. Thereafter, the paper presents empirical findings, before moving to discuss the implications of the findings. A brief concluding section ends the paper.

\section{Prior research on teaching sustainability}

Business educators across the world are integrating sustainability concepts into their curricula to emphasise the importance to future business leaders (Figueiro and Raufflet, 2015). Initiatives range from the insertion of simple materials, activities and examples into existing courses, to the complete revision of curricula in order to embed sustainability into student learning (Figueiro and Raufflet, 2015). Across this spectrum, sustainability itself may be viewed and taught as either a complex concept (Kurland et al., 2010; Wu, Huang, Kuo and Wu, 2010) or a simple process (Figueiro and Raufflet, 2015). The result is a widely divergent range of teaching strategies. 
Treating sustainability as a simple process enables easy integration with the rest of the teaching program. However, it is unwise to do so, as sustainability is widely understood to be highly complex (see UN PRME, n.d.; World Commission on Environment and Development, 1987). By contrast, if sustainability is treated as a complex process, it is not a state of being, but requires a continuously adaptive society in which major challenges are addressed holistically (Miller et al., 2011). Teaching students about sustainability therefore requires a student-centred teaching strategy (Erskine and Johnson, 2012) that enables students to think about their learning in fundamentally different ways (Kurland et al., 2010). Sustainability in business education requires students to become self-reflective, critical thinkers that pursue social action (Figueiro and Raufflet, 2015; Schön, 1987). The introduction of sustainability education, therefore, presents something of a challenge to classical business education structures, suggesting the need for something of a restructuring, "towards a more interactive [model]" (Figueiro and Raufflet, 2015, p. 29).

Teaching sustainability through frameworks and concepts alone is unlikely to win over the hearts and minds of students towards wanting to provide a positive impact on society through action. In order to induce action, more hands-on experiences are required (Stead and Stead, 2010). Education must integrate analytical, physical and spiritual concepts into the students learning activities (Shrivastava, 2010). Sustainability may consequently be embedded into curricula in various ways, including traditional lectures, case studies, simulations (see Salas et al., 2009), experimental learning, and service learning (see, Brower, 2011 and Figueiro and Raufflet, 2015), each of which relates to specific benefits. The impact and success of all available teaching methods is strongly dependent on the values, capabilities and motivations of educators. This dependence exists because sustainability requires individuals to explore their personal values in relation to their specialist disciplinary field and experience (Holdsworth et al., 2008). Educators therefore play a key role "in developing and presenting the values associated with sustainability, hence it is critical that they have the understanding and capacity to impart this knowledge" (Holdsworth et al., 2008, p. 135).

Understanding the challenges that educators face is important because designing a curriculum for sustainability education is as much about educator's learning as it is about student's learning (de la Harpe and Thomas, 2008; Jones et al., 2010). For educators, inhibitors that may restrict a willingness to embed sustainability into teaching include, if they: perceive sustainability to be located outside their disciplinary area and are uncomfortable teaching a multidisciplinary concept; believe that they lack the necessary knowledge, skills and experience to teach sustainability; and feel the ethos of their institution does not support the integration of new content or teaching in existing programmes (Jones et al., 2010). Thus, understanding the challenges of educators in developing and implementing a sustainability teaching initiative is an important area of research. While the creation of a list of potential challenges for educators is easily achieved, empirical evidence of challenges faced by educators implementing sustainability in their teaching activities is absent from the literature, despite the societal importance of expanding sustainability education in business schools. 


\section{Tools and Approaches for Teaching Sustainability}

Given the challenges outlined above, many educators have turned to practical tools or approaches to teach sustainability through student's firsthand experiences. Underpinning this pedagogical approach is experiential learning theory, whereby students build on existing knowledge through constructing new knowledge through engagement in social activities and experiences with the world (Kolb, 1984). Experiential learning has long been upheld as theoretically informing higher education practices, and more recently has been supported as valuable for business education (see Gonzalez-Perez et al., 2019) and more specifically for sustainability education (for example, Dean et al., 2018; Perkiss et al., 2019).

A range of online and offline tools and approaches exists to teach sustainability that promote practical, experiential learning. For example, recently simulations and gamification have been introduced to transform classroom experiences for business students (Alexander and Barndard, 2019; Reade and McKenna, 2019). Specifically, for teaching sustainability development, findings indicate that the higher the students' motivation to participate, the more effective the game for influencing attitudes towards substantiality (Gatti et al., 2019). This suggests that the level of students' engagement is crucial to the success of the implementation of tools or approaches for teaching sustainability. In a global context, initiatives have emerged to support students learning of sustainability, that leverage open-source materials and platforms. Among these are Sulitest (sustainability literacy test ${ }^{1}$ ), the Aim2Flourish initiative ${ }^{2}$, and Mary Gentille's 'Giving Voice to Values (GVV) ${ }^{3}$ ' that each can be adapted to learning contexts, depending on an educators goals, and have been taken up by universities around the world (Storey et al., 2017).

In addition to these global sustainability teaching initiatives, is the WikiRate platform, which was launched as a tool for universities in 2016, the information being disseminated via national chapters of the PRME. WikiRate is an online, crowdsourced database and research tool for asking detailed questions and providing answers on corporate environmental, social and governance (ESG) impacts (WikiRate, 2019). The organization behind the platform is the WikiRate Project e.V., a not-for-profit organization which aims to improve the accessibility and comparability of sustainability information. The WikiRate database is organized around hundreds of indicators and metrics associated with the Sustainable Development Goals (SDGs), Global Reporting Initiative (GRI) and others. It allows educators to provide students with a practical sustainability experience in a range of contexts. Through the tool, students can research organizations and explore their CSR reports for SDG indictors. Information developed by students is then placed on the public WikiRate website to advance sustainability reporting initiatives internationally. While other research has focused on the WikiRate platform as a tool for sustainability education (Dean et al., 2019), or the impact of WikiRate on student learning (Perkiss et al., 2019), this study focuses on the perceptions and challenges of those educators who teach sustainability, using WikiRate as a tool for doing so.

\footnotetext{
${ }^{1}$ https://www.sulitest.org/en/index.html

${ }^{2}$ https://aim2flourish.com

${ }^{3}$ https://www.darden.virginia.edu/ibis/initiatives/giving-voice-to-values/
} 
In summary, this paper aims to support educators interested in integrating sustainability focused teaching activities into their teaching by providing empirical evidence of the challenges faced by international educators who have implemented WikiRate as a teaching tool. Specifically, the paper investigates the following questions: How and why do educators use sustainability tools to embed sustainability education into business and management courses? What challenges and lesson do educators perceive in teaching sustainability education?

\section{Method}

This paper investigates educators' intentions in teaching the complex phenomenon of sustainability and the issues with which they grapple when doing so. To do so, we focused specifically on the implementation of a sustainability teaching tool, WikiRate. The WikiRate tool was chosen because it is relatively new, is explicitly focussed on sustainability, has clear practical applications, and its use in higher education is expanding. In early 2018, the team engaged with the provider of the WikiRate tool to identify potential research participants. At that time, a total of seven educators had adopted the WikiRate platform in their teaching. All seven participated in the research, which involved participating in a series of interviews. Research participants were based at seven different higher education institutions from across the globe and were engaged in teaching a variety of business and management courses at different levels, both sustainability-specific and business-related subjects with sustainability embedded. Despite their different national and institutional settings, all educators implemented the same sustainability education tool, allowing for an assessment of common design and implementation challenges across different contexts.

Each interview was conducted after the course in which the educator had used the WikiRate platform. An interview schedule appears in Annex 1. Both face-to-face and Skype interviews were conducted, with each interview lasting between 45 and 90 minutes. Table 1 provides basic information on each institution and course involved in the study.

\section{INSERT TABLE 1 HERE}

At the end of the process, all interviews were transcribed and suitably anonymized for analysis. As the researchers sought to capture commonalities of experience rather than understand organizational processes or underlying dynamics, the data lent itself to a thematic analysis. Thematic analysis is inductive and flexible and provides access to empirical material to open the possibility for communication of ideas and findings (Boyatzis, 1998). This involved a process of making sense of the educator's responses around the WikiRate case study. The analysis involved iteratively reading, coding and categorising the material to make sense of the data. As Spiggle (1994) notes, there is no universal template for interpreting qualitative data. The data drove the analytic process in this instance; given the nature of the research, it did not make sense to impose predefined categories on the data. The analysis was conducted by four researchers in the following way. In the first phase, the researchers independently read the transcripts several times, developing initial codes. At the end of the process, the researchers 
met and compared notes. In this phase, the research team began grouping, "previously identified categories into more general, conceptual classes" (Spiggle, 1994, p. 493). This was made easier by the high level of inter-coder agreement. In the final phase, the researchers consolidated and fine-tuned the categories into the findings that are presented in the next section. It is worth mentioning that this research formed part of a wider project, in which students from participating universities were also surveyed. While this student-facing data has been published elsewhere (Author, 1; Author, 2), the focus of this study was to explore educators' experiences.

\section{Findings}

The current study evaluates the embedment of a specific sustainability teaching tool, WikiRate, into a range of existing curricula. The unitized tool was sufficiently flexible to be applied in situations where the educator could have perceived sustainability as a complex problem or a simple process. A review of educators' responses on their intentions for, and experiences in, teaching sustainability revealed several categories of interest, which are presented under two broad areas: intended benefits and learning outcomes; and implementation challenges.

\section{Intended benefits and learning outcomes}

This perception aligns with literature that identifies experiential learning or learning-by-doing activities as important sustainability education mechanisms (Figueiro and Raufflet, 2015; Dean et al., 2018). Data indicates that all interviewed educators considered sustainability as a complex process and aimed to develop and implement active, student-centric teaching strategies that support the development of a holistic and integrated understanding of sustainability in business. Educators' intentions for their students are summarized in the themes presented below.

\section{Critical thinking}

The provision of opportunities for critical analysis of corporate sustainability activities and data represented a key intention for educators. Critical thinking combines reasoning and judgement in complex systems, guided by procedural knowledge and a purposefully questioning mindset (Wilkin, 2017). Given the complexity involved in sustainability and/or sustainable development, students' critical thinking skills represent a key area for sustainability education (Thomas, 2009). Although critical thinking may be viewed as a transferable skill, sustainability education (Lozano, 2010), as well as critical thinking (Moore, 2013), are highly contextualised skills within a given discipline environment.

Respondents were generally positive about the specific teaching tool, WikiRate, to encourage critical thinking in students. This was evident in their intentions, or reasons for using the tool, "I thought for my teaching it was useful as a way of helping students to understand what that data actually meant. You see a company is rated as wonderful, well, great - what does it mean? It helps their critical thinking." (Respondent (R) 7). For this educator, and others, the development of critical thinking was closely bound to the notion that students were engaged in practical, experiential learning. This educator elaborated "It's also something practical. I like 
having practical exercises and so on in my teaching, and this was very well-suited to that." ( $\mathrm{R}$ 7). Another concurred, relating critical thinking as useful for teaching complex concepts, and reflected on the delivery mode, "I think they were able to be a bit more analytical in their thinking, rather than just taking what I say" (R 4). Similarly to the educator above, this comment was aligned to the practical nature fo the activity, "It was a bit more interactive, and they had to think a bit more than some of the other courses" (R 4). The development of criticalthinking skills around concepts of sustainability is significant for preparing graduates for a global workplace.

\section{Learning by doing}

As indicated above, closely connected with the growth of critical thinking, was the provision of active learning tasks to provide a space for the exploration of complex concepts. Through WikiRate, students can grapple with a practical issue and real organisational practices to learn about sustainability. This experiential or learning-by-doing pedagogy emerged as an important intention for educators adopting the teaching tool. Educators suggested that they were motivated to use WikiRate because they 'wanted to give [students] something that is applied, that relates more to analyzing what companies do' (R 7). And thus, using the WikiRate activity enabled students' to 'have hands on experience on reporting [and become] familiar with a specific metrics' (R 1).

Respondents also reported that they valued the practical nature of the exercise, for example:

I thought it'd be a great opportunity to link industry as well as research within the curriculum, especially in our context, because we do have students who have had significant work experience as well. So I think it was the linking the practical experience and the research aspect, and to really test what's going on in the market, and how we can contribute to that. (R 4)

The practical nature of the activity lends itself to problem solving, critical thinking and enhanced engagement because it brings the complexities associated with sustainability to the forefront of the students learning activities.

\section{Fostering real-world engagement}

Closely related to the educators' intention of enabling a learning-by-doing pedagogy is the concept of real-world engagement. Educators highlighted the ability of students to relate and apply complex theoretical constructs to their local contexts as a key benefit that was associated with engagement with their local (national) real-world setting. In addition, the use of a realworld analysis tool for teaching purposes was identified as being an important intention for educators.

The use of identifying real-world problems, and the application of real-world problem-solving methods to resolve these problems, is highly important for sustainability education (Lozano, 2010). Given that the pursuit of sustainability requires actions by individuals and corporations, literature recommends the use of an active learning approach (Erskine and Johnson, 2012). The active participation in real-world problem solving activities supports students in becoming 
responsible citizens (Anderberg et al., 2009). In this vein, respondents found that using local companies - those with which students could readily identify and for whom content was available in their own language - was highly beneficial. The following quotes provide contextspecific examples:

[We] focused more on [own country] companies in the first year... So in the [own country], say, financials industry, students could see there are some areas that are quite similar in terms of disclosure, and what some of the differences are, if any. [A question asked was] Do we have some that are really stars in their field, disclosing a lot of information? It's about just trying to get a better understanding of the [own country] market. (R 4)

The benefit of using local companies extended to the use of companies from international students' home countries. One educator deliberated, "I selected a number of companies, which included a large proportion of Chinese companies to give to the Chinese students... They could go to their own Chinese language websites and find out information" (R 6). Because sustainability can be interpreted differently in different contexts (Figueiro and Raufflet, 2015), educational activities that focus on sustainability are likely to be better understood when related to the discipline and national contexts in which students are located (Lozano, 2010). It appears likely that educators used local companies to allow domestic students to recognize the names of the companies they are investigating, hence improving the "real-world" factor for students. This in turn allows students to develop a more applied and contextualised knowledge of sustainability, and hopefully induce personal interest in the impact of corporate sustainability actions and reporting within the students' local context.

\section{Implementation challenges}

Sustainability education as well as the use of technology in teaching are both complex and laced with challenges for educators. Literature highlights that the implementation of sustainability education programs is impacted by organizational capacity and pedagogical restrictions (Figueiro and Raufflet, 2015), while technology adoption challenges relate predominantly to organizational cultures and structures (Zhu 2015), as well as educators' personal perceptions and support needs (Islam et al., 2015; Englund et al., 2017). The implementation challenges discussed by the respondents related to the limitations for sustainability education imposed by insitutional structures, as well as the technological challenges posed by the use of an unfamiliar teaching tool.

\section{Institutional structures}

The most significant challenge in the activity was associated with the institutional structures of formal education. These, as Schön $(1987$, p. 8) puts it, are "premised on technical rationality" and not always suited to addressing complex issues. In the accounting discipline, e.g., curricula has traditionally focused on the teaching of technical knowledge: accounting education therefore lacks opportunity to address social transformation and transferable skills (Dean et al., 2018; Bayerlein, 2015). One educator expressed the problem as follows: 'It was a challenge just to design an appropriate curriculum [on] sustainability and social responsibility' (R 4). The issue identified here, highlights that educators may not be experts in sustainability, 
necessitating training and support for educators to ensure that existing sustainability frameworks are well understood, and suitably integrated into existing curricula (Cebrian and Junyent, 2015).

The challenge of institutional structures was most particularly evident when discussing assessments or evaluation of student learning outcomes, that is, the formal assurance of learning processes at each institution. One educator demonstrates grappling with these formal parameters:

$[\mathrm{H}]$ ow are you going to assess it? Are you going to use it as a formative assessment or as a summative assessment? In my case I think it's a combination of both formative and summative... Because my modules are in the [particular] system, 20 credits, equivalent to 200 hours of notional learning, I could not see a way where I could only do an assignment based on WikiRate. (R 2)

Of the seven respondents, six educators used the WikiRate tool for assessment/grading purposes, however deciding how to assess students came with challenges.

One educator described the assessment process as not straight forward. While they saw value in summative assessment, institutional structures prevented this application, saying:

It's not marked. It's not assessed in any way. [Students] don't hand anything in. ... I certainly couldn't assess it summatively, because we have very strict rules, and if I want to change summative assessment I have to go through a [long] process (R 7).

These reflections suggest that teaching sustainability includes compromises and adaption to implement the activity within the parameters of institutional discourses, processes and structures for student learning. Beyond the institutional structure concerns, challenges were also reported in relation to the learning the WikiRate tool itself.

\section{Learning the tool}

Respondents experienced challenges associated with the exercise itself; both in terms of the challenges involved in learning how to use the tool themselves and in the level of support that students required in order to derive full benefit from the exercise. Educators themselves experienced something of a learning curve for using the WikiRate tool. This meant that they needed technical support in order to use WikiRate effectively, i.e., R 1 argued that if [WikiRate support] wasn't supportive with us we'd have given up on it. But [they are] very, very good with us'. Another educator expressed a similar appreciation:

To be honest with you, when we started it I myself was not sure about how to do the WikiRate analysis on the platform. I was ultra-dependent on [WikiRate support] because when questions arose, e.g., of a technical nature and reporting nature, students were able to send a message to info@wikirate.org, and [WikiRate support] would respond very quickly. To be honest with you, in both years without that support it would not be as good. (R 2) 
The novelty of the WikiRate tool is part of the technical-challenge issue, it is not widely known and there is little experience to draw upon. If you are tech-savvy then, as this educator puts it, you have to get familiar with the website, and once you understand the idea, you have a project, you have a company, you have indicators and it's fine' (R 3). Nonetheless, the WikiRate tool had a clear learning curve, which seems likely to be evident in the introduction of other tools for sustainability teaching.

The challenge of the new tool is not only reflected in the need for technical support. One educator describes introducing the tool also needs engagement from relevant teaching staff, "...quite independent of WikiRate, you'd need whoever's doing the teaching to understand and get the concept. ... If you have a tutor who doesn't understand that and isn't engaged, then you can't have these things [like WikiRate]" (R 7). In addition to facing challenges relating to the learning of the tool, respondents clearly indicated that students also required support. For example, 'students found it quite complicated' and 'intimidating' (R 1); that students felt 'overwhelmed because it can seem very complex' ( $\mathrm{R} 7$ ), and that the 'first step is always the hardest, because that's when they're inputting mechanically the numbers' ( $\mathrm{R} 4)$. The specific numbers and metrics also presented a significant learning curve, as illustrated:

[F]or students that never have heard about $\mathrm{CO}_{2}$ emissions and stuff like that it's quite difficult to even understand the data. So I would maybe use the platform again but with a much easier data set so we have maybe only employees, a number of employees, I don't know, budget, overhead, benefit, for example. (R 3)

One consequence of students' need for support is that additional time and training was needed for the exercise. It also meant that, to some extent, the WikiRate exercise was a dual one - the intended sustainability related learning and something of a mechanical process of learning to follow the steps of the exercise. In a time-constrained syllabus with limited teaching time, this had the consequence of detracting from students' ability to focus on the more complex and wider issues of sustainability.

The final hurdle related to the WikiRate tool is language. For non-native speakers of English at an institution where English is not the medium of instruction, many students are 'afraid of the site being in English' (R 5). Even at an English-speaking university, English is not always a strong point ... we have a number of foreign non-native speakers for undergraduate, but the number is much higher in postgraduate' (R 7). These findings indicate the challenges and hurdles of using WikiRate for sustainability education. Arguably, any complex tool (as is required to teach sustainability) is likely to have a learning curve and time-challenges associated with it. While this analysis identifies issues that are particular to WikiRate, we can generalize to some extent from the individual case.

\section{Discussion}

The existing literature has illustrated numerous successful cases, many of which employing experiential learning approaches, to sustainability education in business education (see Figueiro and Raufflet, 2015; Author, 1). While this paper is based on a similar case study 
methdology, revolving around the implementation of a new sustainability teaching tool, its focus - on educators' intentions and challenges- differs substanially from prior literature. The findings of this paper have interesting implications for the teaching of sustainability, as well as the adoption of teaching techology both within and oustide sustainability education.

Overall, the findings of this paper confirm prior literature (Holdsworth et al., 2008; de la Harpe and Thomas, 2008; Jones et al., 2010) that sustainability education is a complex area in which the perceptions and abilities of educators affect the design, implementation and impact of teaching activities substantially. All educators in this study perceived sustainability to be a complex issue (see Kurland et al., 2010; Wu et al., 2010). As a result, educators utilized an experiential learning approach, specifically the WikiRate tool, to provide students with the holistic (Miller et al., 2011), student centric (Erskine and Johnson, 2012) and hands-on (Stead and Stead, 2010) learning experince that the literature recommends for successful sustainability eduation.

The first major theme of the findings section - intended benefits and learning outcomes - were sub-categorized into key inter-related areas such as critical thinking and learning by doing. These have wide applications across the teaching and learning field and are congruent with the existing literature. That is, they are useful, but break no new ground. The focus of this discussion is therefore on the second major theme - implementation challenges. This is indeed new and can be categorized into two clearly distinct areas: 'institutional structures' and 'learning the tool'. Both can be applied to teaching sustainability (beyond the WikiRate tool).

Despite educators' attempts, several challenges were associated with the development and implementation of sustainability in existing curricula, e.g. institutional structures, as well as the use of the specialized educational tool underpinning this project. The lessons learned from the project is that meaningful and transformative sustainability education requires an institution that allows flexibility in teaching and assessment. There is a clear need for more work on tertiary institutions' institutional processes and how they affect teaching on sustainability and other complex issues. Moreover, as the learning the tool theme makes clear, tools for teaching on complex issues could well themselves be complex, requiring a certain amount of investment. Faculty seeking to use such tools would be well-advised to pay attention to the available support, and to make a decision on using the tool contingent upon there being good support. Our findings are also relevant for teaching other complex matters that are not necessarily a good epistemological fit with the technical rationality of the university environment, with its normative curriculum and instrumental problem-solving approach (following Schön, 1987).

Another clear pedagogical implication from the research presented here - and one that makes a major contribution - is that educators will need to be aware of two kinds of challenge: standard pedagogy (multisided peg into a round hole) and the epistemological incompatibility that comes with teaching sustainability. This makes sustainability teaching an unusually challenging endeavour, possibly uniquely in a business school setting. Educators have understandable and praiseworthy learning outcomes, but they must face meta-challenges that colleagues in other areas do not face. Schön (1987) alluded to such issues a generation ago, but they appear to be still with us. Whilst this is not the place to develop a fully-mature theory of 
pedagogy for sustainability, several questions/factors are salient in designing sustainability education. Firstly, is the need for education and adaptation of the SDGs. This is an urgent matter because of the changes needed in wider society and the desired transition to greater sustainability. Could educators work more closely with companies in order to partially bypass the organizational structures of their curricula? That is, could educators use sustainability as the 'hook', but with awarded grades being related to other aspects of working with organizations, for which students would need to engage deeply with sustainability in order to work well? Alternatively, the SDGs may provide an opportunity to integrate sustainability more strongly into the curriculum, given their strong uptake by business. Any tools for teaching the SDGs would be useful in this respect.

The limitation of this research is that, although the interviews conducted for the research covered $100 \%$ of the population under investigation, the number is nonetheless modest. Further research into faculty experience of sustainability teaching is therefore needed, arguably covering the use of a range of individual tools. Similarly, although we posit a degree of generalizability on the basis of this individual case (see Tsang, 2014), similar research in other areas would be highly valuable. Moreover, longitudinal research into educators' experience of the WikiRate platform (or other sustainability education tools) would be useful.

\section{Conclusion}

This paper has made several contributions to the literature. It has presented a new pedagogical tool for sustainability education and feedback on the tool through interviews with educators. Such is relevant for any teachers aiming to embark on sustainability teaching in business and management education. Our current systems, organizational structures and student cohorts present areas that require compromises in curriculum design. It appears impossible in the current system that sustainability teaching by itself will achieve wider changes. As a result, teachers should work with the compromises until sustainable development is further embedded across society. Further, and more practically, this research has implications and questions for the educator seeking to embed sustainability more thoroughly into their course.

To conclude, our key message is that there is a great deal for educators to learn for implementing sustainability into curriculum, essentially by autodidactic 'learning by doing'. It is a space where educators may not be the expert and therefore it requires experimentation and reflection. When teaching sustainability, there will be challenges and compromises, adaptations and improvements. Therefore, and for now, educators need to reframe how we approach sustainability education and expose the limitations, which constrain teaching practices to conform to current institutional settings that may be becoming increasingly not fit for purpose. By reframing the parameters of our challenges, we may start to look beyond 'plugins' for teaching sustainability education and find new solutions that enable the teaching of complexity without reduction or simplification. These solutions will not occur easily or quickly. But rather require us as a global collaborative of business and management educators to connect, imagine and think laterally about how we will teach suitability to empower future leaders to navigate the mess and complexities of business within the socioecological world. 
Therefore, along with the calls for future research, we also call for innovative teaching that aims to break beyond traditional organizational boundaries and do new things, i.e. out-ofclassroom based learning and active and/or service learning that embeds community projects/internships/engagement. 


\section{References}

Aleander, E.A. and Barnard, S. (2019). "Not just game play: enhancing the international student experience through the use of computer-based simulations" (pp. 609-632). In V. Taras, M.A. Gonzalez-Parez, K. Lynden (Eds.). The Palgrave Handbook of Learning and Teaching International Business and Management, Palgrave Macmillan, Switzerland.

Anderberg, E., Norden, B. and Hansson, B. (2009). "Global learning for sustainable development in higher education: Recent trends and a critique", International Journal of Sustainability in Higher Education, Vol. 10 No. 4, pp. 368-378.

Bayerlein, L. (2015). "Curriculum innovation in undergraduate accounting degree programmes through "virtual internships". Education + Training, Vol. 57 No. 6, pp. 673-684.

Bebbington, J. and Unerman, J. (2018), "Achieving the United Nations Sustainable Development Goals: an enabling role for accounting research", Accounting, Auditing and Accountability Journal Vol. 31 No. 1, pp. 2-24.

Boyatzis, R. (1998). Transforming qualitative information: Thematic analysis and code development. Sage Publications. Thousand Oaks, CA.

Brower, H. H. (2011). "Sustainable development through service learning: A pedagogical framework and case example in a third world context", Academy of Management Learning \& Education, Vol. 10, pp. 58-76.

Cebrian, G., and Junyent, M. (2015). "Competencies in education for sustainable development: Exploring the student teachers' views”. Sustainability, Vol. 7 No. 3, pp. 2768-2786

Dean, B. A., Perkiss, S., Simic Misic, M. and Luzia, K. (2018), “Transforming accounting curricula to enhance integrative learning", Accounting \& Finance. DOI: 10.1111/acfi.12363.

Dean, B., Gibbons, B. and Perkiss, S., (2019), "An experiential learning activity for integrating the Sustainable Development Goals into Higher Education business curriculum". Social Business, Vol. 8, pp. 387-409

Doyle, T. M. (2018). Ratings that don't rate: The subjective world of ESG ratings agencies. Washington, D.C.: American Council for Capital Formation. Retrieved Dec 13, 2019, from http://accfcorpgov.org/wp-content/uploads/2018/07/ACCF_RatingsESGReport.pdf

Dumay, J., Bernardi, C., Guthrie, J. and Demartini, P. (2016) "Integrated reporting: a structured literature review", Accounting Forum, Vol. 40: 2016, pp. 166-185.

Englund, C., Olofsson, A.D. and Price, L. (2017). "Teaching with technology in higher education: Understanding conceptual change and development in practice". Higher Education Research \& Development, Vol. 36 No. 1, pp. 73-87.

Erskine, L. and Johnson, S.D. (2012). "Effective learning approaches for sustainability: A student perspective", Journal of Education for Business, Vol. 87 No. 4, pp. 198-205.

European Commission (2019). The European Union and countries worldwide join forces to mobilise private investors for financing the green transition. Press release, 18 October 2019. Retrieved Oct 29, 2019, from https://ec.europa.eu/info/sites/info/files/business_economy_euro/banking_and_finance/doc uments/191018-international-platform-sustainable-finance-press-release_en.pdf

Figueiro, S.P. and Raufflet, E. (2015). "Sustainability in higher education: a systematic review with focus on managment education", Journal of Cleaner Production, Vol, 106, pp. 2233.

Gatti, L., Ulrich, M. and Seele, P. (2019). "Education for sustainable development through business simulation games: An exploratory study of sustainability gamification and its effects on students' learning outcomes". Journal of cleaner production, Vol 207, pp.667678.

Ghoshal, S. (2005). "Bad management theories are destroying good management practices", Academy of Management Learning \& Education, Vol. 4, pp. 75-91. 
Gonzalez-Parez, M. A., Lynden, K. and Taras, V. (2019). The Palgrave Handbook of Learning and Teaching International Business and Management, Palgrave Macmillan: Switzerland.

Heithaus, T., Mills, R., and Perkiss, S. (2018). Disclosure and reporting against the Sustainable Development Goals: Connecting new stakeholders to sustainability data. PRME and WikiRate e.V.: Berlin. Retrieved Oct 29, 2019, from https://tinyurl.com/y7s6e24u

Islam, N., Beer, M. and Slack, F. (2015). "E-learning challenges faced by academics in higher education", Journal of Education and Training Studies, Vol. 3 No. 5, pp. 102-112.

Kolb, D. (1984). Experiential learning: Experience as the source of learning and development. Englewood Cliffs, NJ: Prentice-Hall, Inc.

Kurland, N.B., Michaud, K.E.H., Best, M., Wohldmann, E., Coxz, H., Pontikis, K. and Vasishth, A. (2010). "Overcoming silos: the role of an interdisciplinary management course in shaping a sustainability network", Academy of Management Learning and Education, Vol. 9 No. 3, pp. 457-476.

Lozano, R. (2010). "Diffusion of sustainable development in universities' curricula: an empirical example from Cardiff University", Journal of Cleaner Production, Vol. 18 No. 7, pp. 637644.

Lozano, R. (2018). "Sustainable business models: Providing a more holistic perspective", Business Strategy and the Environment, Vol. 27 No. 8, pp. 1159-1166.

Miller, T.R., Munoz-Erickson, T. and Redman, C.L. (2011). "Transforming knowledge for sustainability: towards adaptive academic institutions", International Journal of Sustainability in Higher Education, Vol. 12 No. 2, pp. 177-192.

Moore, T. (2013). "Critical thinking: seven definitions in search of a concept", Studies in Higher Education, Vol. 38 No. 4, pp. 506-522.

Parris, D. L. \& C. McInnis-Bowers (2017). "Business Not as Usual: Developing Socially Conscious Entrepreneurs and Intrapreneurs", Journal of Management Education, Vol. 41, pp. 687-726.

Perkiss, S., Dean, B.A., Gibbons, B., Heithaus, T., Wersun, A., Gonzalez-Perez, M.A., ... Mills, R. (2018). WikiRate Student Engagement Report: International Case Studies. University of Wollongong, WikiRate \& PRME: Wollongong. Retrieved from https://ro.uow.edu.au/buspapers/1503/

Persons, O. (2011). "Incorporating Corporate Social Responsibility and Sustainability into a Business Course: A Shared Experience", Journal of Education for Business, Vol. 87, pp. 63 72.

Poland, B. D. (2003). Transcription quality. In J. A. Holstein \& J. E. Gubrium (Eds.), Inside interviewing: New lenses, new concerns (pp. 267-288). Sage. Thousand Oaks, CA.

Porter, T. and J. Córdoba (2009). "Three Views of Systems Theories and their Implications for Sustainability Education”, Journal of Management Education, Vol. 33, pp. 323-347.

Pratt, M. G. (2009). "For the lack of a boilerplate: Tips on writing up (and reviewing) qualitative research", Academy of Management Journal, Vol. 52, pp. 856-862.

Reade, C.,Todd, A.M., Osland, A and Osland, J. (2008). "Poverty and the Multiple Stakeholder Challenge for Global Leaders", Journal of Management Education, Vol. 32, pp. 820-840.

Reade, C. and McKenna, M. (2019). "The Trade Barrier Game: An experiential approach to understanding political behavior in trade negotiations" (pp. 633-666). In V. Taras, M.A. Gonzalez-Parez, K. Lynden (Eds.). The Palgrave Handbook of Learning and Teaching International Business and Management, Palgrave Macmillan, Switzerland.

Salas, E., Wildman, J. L. and Piccolo, R.F. (2009). "Using simulation based training to enhance management education", Academy of Management Learning \& Education, Vol. 8, pp. 559573.

Schön, D. A. (1987). Educating the reflective practitioner: Towards a new design for teaching and learning in the professions. Jossey-Bass. San Francisco, CA.

Seager, T. P., Collier, Z.A., Linkov, I. and Lambert, J.H. (2013). "Environmental sustainability, complex systems, and the disruptive imagination", Environment Systems and Decisions, Vol. 33, pp. 181-183. 
Senge, P., Aleiner, A., Roberts, C., Ross, R., and Smith, B. (1994). The fifth discipline fieldbook: Strategies and tools for building a learning organization. Doubleday. New York.

Shrivastava, P. (2010). "Pedagogy of passion for sustainability", Academy of Management Learning and Education, Vol. 9 No. 3, pp. 443-455.

Silverman, D. (20019: Interpreting qualitative data: Methods for analysing talk, texts and interaction (2nd Edition). Sage. London.

Spiggle, S. (1994). "Analysis and interpretation of qualitative data in consumer research", Journal of Consumer Research, Vol. 21, pp. 491-503.

Snelson-Powell, A., Grosvold, J. and Millington, A. (2016). "Business school legitimacy and the challenge of sustainability: A fuzzy set analysis of institutional decoupling", Academy of Management Learning \& Education, Vol. 15, pp. 703-723.

Starik, M., Rands, G.P. and Marcus, A.A. (2010). "From the guest editors: In search of sustainability in management education", Academy of Management Learning \& Education, Vol. 9, pp. 377-383.

Starik, M. and Rands, G. (1995). "Weaving an integrated web: Multilevel and multisystem perspectives of ecologically sustainable organizations", Academy of Management Review, Vol. 20, pp. 908-935.

Stead, J.G. and Stead, W.E. (2010). "Sustainability comes to management education and research: A strory of coevolution", Academy of Management Learning and Education, Vol. 9 No. 3, pp. 488-498.

Storey, M., Killian, S., \& O'Regan, P. (2017). "Responsible management education: Mapping the field in the context of the SDGs". The International Journal of Management Education, Special Issue: Principles for Responsible Management Education (PRME), 15(2), pp. 93-104.

Tekarslan, E. and Erden, N.S. (2014). "A Review of Business Education around the Globe: Future Transitions", Journal of Multidisciplinary Research, Vol. 6, pp. 49-64.

Thomas, I. (2009). "Critical thinking, transformative learning, sustainable education, and problem based learning in universities", Journal of Transformative Education, Vol. 7 No. 3, pp. 245264.

United Nations Principles for Responsible Management Education (nd). History. United Nations Principles for Responsible Management Education website. Retrieved Sept 13, 2019, from https://www.unprme.org/about-prme/history/index.php

Waddock, S. (2006). Leading corporate citizens: Vision, values, value-added (2nd Ed.). McGraw Hill. New York.

Wang, L., Malhotra, D. and Murnighan, J. K. (2011). "Economics education and greed", Academy of Management Learning \& Education, Vol. 10, pp. 643-660.

WikiRate. (2019). WikiRate. Retrieved September 4, 2019, from www.wikirate.org

Wilkin, C.L. (2017). "Enhancing critical thinking: accounting students' perceptions", Education + Training, Vol. 59 No. 1, pp. 15-30.

Wood, R. (1999). The future of strategy: The role of the new sciences. In M. Lissack \& H. Gunz (Eds.), Managing complexity in organizations: A view in many directions (pp. 118-162). Quorum Books. Westport, CT.

World Commission on Environment and Development. (1987). Our common future. Oxford: Oxford University Press.

Wu, Y.J., Huang, S., Kuo, L. and Wu, W. (2010). "Managment education for sustainability: a webbased content analysis", Academy of Management Learning and Education, Vol. 9 No. 3, pp. 520-531.

Zhu, C. (2015). "Organisational culture and technology-enhanced innovation in higher education", Technology, Pedagogy and Education, Vol. 24 No. 1, pp. 65-79.

Author, 1

Author, 2 
Table 1: Global case study partners and the courses in which they used WikiRate in 2018

\begin{tabular}{|c|c|c|c|c|c|}
\hline University & Country & Level & Discipline & Size & Course description \\
\hline & \multirow[b]{2}{*}{ Australia } & $\begin{array}{l}\text { Undergraduate } \\
\text { (first year) }\end{array}$ & Accounting & 42 & Introductory accounting \\
\hline & & $\begin{array}{l}\text { Undergraduate } \\
\text { (final year) }\end{array}$ & Commerce & 760 & Business capstone \\
\hline B & Austria & $\begin{array}{l}\text { Undergraduate } \\
\text { (final year) }\end{array}$ & $\begin{array}{c}\text { Institute } \\
\text { Business } \\
\text { Administration } \\
\text { \& Management }\end{array}$ & 82 & $\begin{array}{l}\text { Case studies in business } \\
\text { and sustainability }\end{array}$ \\
\hline $\mathrm{C}$ & Colombia & $\begin{array}{l}\text { Undergraduate } \\
\text { (final year) }\end{array}$ & Management & 300 & CSR course \\
\hline $\mathrm{D}$ & Colombia & $\begin{array}{l}\text { Undergraduate } \\
\text { (final year) }\end{array}$ & $\begin{array}{c}\text { Business \& } \\
\text { Economic } \\
\text { Sciences } \\
\end{array}$ & 27 & Ethics and CSR \\
\hline $\mathrm{E}$ & $\begin{array}{c}\text { UK } \\
\text { (England) }\end{array}$ & Postgraduate & Management & 130 & $\begin{array}{l}\text { Project work for } \\
\text { managers - } \\
\text { sustainability and } \\
\text { society }\end{array}$ \\
\hline $\mathrm{F}$ & $\begin{array}{c}\text { UK } \\
\text { (Scotland) }\end{array}$ & $\begin{array}{l}\text { Undergraduate } \\
\text { (final year) }\end{array}$ & $\begin{array}{l}\text { Business \& } \\
\text { Society }\end{array}$ & 220 & $\begin{array}{l}\text { Sustainability, corporate } \\
\text { responsibility and ethics }\end{array}$ \\
\hline G & $\begin{array}{l}\text { South } \\
\text { Korea }\end{array}$ & Postgraduate & $\begin{array}{c}\text { International } \\
\text { Studies } \\
\end{array}$ & 14 & $\begin{array}{c}\text { Special topics in } \\
\text { international business }\end{array}$ \\
\hline
\end{tabular}

\section{Annex 1: Interview schedule, semi-structured interviews}

The questions asked included (but not limited to):

- What was the motivation for embedding this activity into your course;

- What were your experiences designing and/or adapting the initiative for your teaching context?

- What support did you get and what would you like to see more of?

- What were the anticipated/unanticipated benefits for you? For the students?

- What were some of the challenges?

- What skills do you feel this activity developed for students? 
Dear Editors,

Thank you for the opportunity to resubmit our manuscript JARHE-02-2020-0029 entitled "Teaching sustainability: Complexity and compromises" which we submitted to the Journal of Applied Research in Higher Education. We have gone through the manuscript in detail and made changes based on the three reviewer's suggestions. Please see details on how we addressed these recommendations in the tables below.

\section{Reviewer 1}

\begin{tabular}{|c|c|c|}
\hline & Reviewer comment & Author response \\
\hline 1 & $\begin{array}{l}\text { The literature review is easy to } \\
\text { comprehend and reads well, but } \\
\text { does not highlight particular } \\
\text { learning or teaching theories } \\
\text { that might be applied to } \\
\text { knowledge from online sources } \\
\text { such as WikiRate. }\end{array}$ & $\begin{array}{l}\text { We are gratified that you found our original literature review } \\
\text { easy to comprehend. Thank you for your suggestion, which } \\
\text { has helped us to improve our manuscript. We have now } \\
\text { introduced a new section to explore 'tools and approaches' } \\
\text { (starting page 4) that are founded in experiential learning. } \\
\text { We briefly outline experiential learning in this section, and } \\
\text { refer to it at the end of the paper. }\end{array}$ \\
\hline 2 & $\begin{array}{l}\text { The respondent sample is more } \\
\text { than adequate for qualitative } \\
\text { data gathering. In fact, it is } \\
\text { enough for statistical analysis. } \\
\text { Cultural differences might also } \\
\text { be mentioned, even though the } \\
\text { balance is not attained (e.g. } \\
\text { Koreans only } 14 \text { postgrad } \\
\text { students, compared to } 760 \\
\text { Australians final year } \\
\text { undergrads). }\end{array}$ & $\begin{array}{l}\text { Thank you for this insight. We agree that quantitative } \\
\text { analysis is possible with this data set. However, it was not } \\
\text { the focus of this paper, and we do not feel that including a } \\
\text { statistical analysis would improve the present paper. We } \\
\text { shall consider how to use our findings further in future, } \\
\text { including using statistical analyses. } \\
\text { We agree that the imbalance of responses from various } \\
\text { countries is notable. Indeed, this, together with the type of } \\
\text { qualitative analysis we prioritised for this paper, are the } \\
\text { reasons that we decided to not discuss cultural differences in } \\
\text { this paper. Moreover, the highly international nature of the } \\
\text { student (and staff) bodies across our sample would make it } \\
\text { particularly challenging to meaningfully discuss cultural } \\
\text { differences. }\end{array}$ \\
\hline 3 & $\begin{array}{l}\text { Yes the results are presented } \\
\text { clearly and analyzed in detail. } \\
\text { However, there is no theory } \\
\text { being tested. It is a study of } \\
\text { interview data -- organizing } \\
\text { them into categories according } \\
\text { to similarities. }\end{array}$ & $\begin{array}{l}\text { You are of course correct that we are not testing theory; in a } \\
\text { qualitative study of this nature, it would have been } \\
\text { inappropriate to do so. We thank you for drawing enhanced } \\
\text { attention to our use of categories, which continue to form the } \\
\text { backbone of the paper. We have now introduced } \\
\text { 'experiential learning' in the new section (page } 4-5 \text { ), } \\
\text { drawing on precedent from others employing this theory to } \\
\text { underpin their study. We have ensured this has also been } \\
\text { linked to the end of the paper. }\end{array}$ \\
\hline 4 & $\begin{array}{l}\text { WikiRate alone may not be the } \\
\text { only online learning tool that is } \\
\text { around to teach and learn about } \\
\text { sustainability. }\end{array}$ & $\begin{array}{l}\text { We fully agree, and apologise that this was not clear in our } \\
\text { original manuscript. A new section has been introduced to } \\
\text { explore 'tools and approaches' that are founded in } \\
\text { experiential learning. It includes the sentence "A range of } \\
\text { online and offline tools and approaches exists to teach } \\
\text { sustainability that promote practical, experiential learning." }\end{array}$ \\
\hline
\end{tabular}

\section{Reviewer 2}

\begin{tabular}{|l|l|l|}
\hline & Reviewer comment & Author response \\
\hline 5 & $\begin{array}{l}\text { The author might consider } \\
\text { incorporating a broader }\end{array}$ & $\begin{array}{l}\text { Thank you for this suggestion. We believe that this reference } \\
\text { fits well with our new section 'tools and approaches' (page }\end{array}$ \\
\hline
\end{tabular}




\begin{tabular}{|c|c|c|}
\hline & $\begin{array}{l}\text { discussion on gamification in } \\
\text { ESD, e.g. Gatti, L., Ulrich, M. } \\
\text { and Seele, P., 2019. Education } \\
\text { for sustainable development } \\
\text { through business simulation } \\
\text { games: An exploratory study } \\
\text { of sustainability gamification } \\
\text { and its effects on students' } \\
\text { learning outcomes. Journal of } \\
\text { cleaner production, 207, } \\
\text { pp.667-678. }\end{array}$ & $\begin{array}{l}\text { 4) and have included the reference in that section, together } \\
\text { with two other recent publications that employ gaming } \\
\text { strategies in business education. }\end{array}$ \\
\hline 6 & $\begin{array}{l}\text { It might be more appropriate } \\
\text { to discuss the WikiRate site in } \\
\text { the Introduction section rather } \\
\text { than the Methodology section. }\end{array}$ & $\begin{array}{l}\text { We agree that discussing WikiRate is not fully appropriate in } \\
\text { the Methodology section. We have therefore moved the } \\
\text { description of WikiRate to the new section (Tools and } \\
\text { approaches, page 4), which is located before the } \\
\text { Methodology section. We think that this new location is the } \\
\text { most appropriate place for the description. We also explicitly } \\
\text { refer to it in the Introduction when WikiRate is first } \\
\text { mentioned. }\end{array}$ \\
\hline 7 & $\begin{array}{l}\text { Perhaps provide a justification } \\
\text { for the selection of } 7 \\
\text { participants, and how this } \\
\text { might affect the validity or } \\
\text { generalisability of the } \\
\text { findings. }\end{array}$ & $\begin{array}{l}\text { Thank you for helping us to tighten up our language. We } \\
\text { have now changed the first paragraph of our Methodology } \\
\text { section. The relevant part now reads: } \\
\text { "In early 2018, the team engaged with the provider of the } \\
\text { WikiRate tool to identify potential research participants. At } \\
\text { that time, a total of seven educators had adopted the } \\
\text { WikiRate platform in their teaching. All seven participated } \\
\text { in the research, which involved participating in a series of } \\
\text { interviews." (page 6) } \\
\text { We do not elaborate on questions of validity and } \\
\text { generalisability in the manuscript, but we feel it appropriate } \\
\text { to make a few additional remarks here. } \\
\text { Our findings are not generalisable in the sense that sound } \\
\text { quantitative research is generalisable, and we do not seek to } \\
\text { claim generalisability; though we are of course interested in } \\
\text { relevance for practice. We certainly do not have a large } \\
\text { enough pool of participants for statistical tests (even if } \\
\text { respondents do represent } 100 \% \text { of the population under } \\
\text { investigation); moreover, the chosen method (interviews) } \\
\text { does not permit a statistical analysis. Here we draw on } \\
\text { Michael Pratt's (2009, p.859) suggestion to "make sure your } \\
\text { chain of evidence is clear" rather than making the error or } \\
\text { seeking to quantify qualitative data (p.858) } \\
\text { We are also wary of claiming validity, as this too is more } \\
\text { associated with quantitative research methods. We are much } \\
\text { more interested in what Wood \& Kroger (2000, p.163) refer } \\
\text { to as warranting, "providing justification and grounds for } \\
\text { one's claims". We trust that our manuscript meets this test. } \\
\text { Pratt, M. G. (2009). From the editors. For the lack of a } \\
\text { boilerplate: Tips on writing up (and reviewing) }\end{array}$ \\
\hline
\end{tabular}




\begin{tabular}{|c|c|c|}
\hline & & $\begin{array}{l}\text { qualitative research. Academy of Management Journal, } \\
\text { 52(5), 856-862. } \\
\text { Wood, L. A., \& Kroger, R. O. (2000). Doing discourse } \\
\text { analysis: Methods for studying action in talk and text. } \\
\text { Thousand Oaks, CA: Sage. }\end{array}$ \\
\hline 8 & $\begin{array}{l}\text { Some detail on the coding } \\
\text { methods might be useful for } \\
\text { the paper. }\end{array}$ & $\begin{array}{l}\text { We apologise for the oversight in our original manuscript of } \\
\text { not including some detail on coding. We have now rectified } \\
\text { this, hopefully to your satisfaction. The new text is located } \\
\text { just after Table 1, page 6, and reads as follows: } \\
\text { "At the end of the process, all interviews were } \\
\text { transcribed and suitably anonymized for analysis. As } \\
\text { the researchers sought to capture commonalities of } \\
\text { experience rather than understand organizational } \\
\text { processes or underlying dynamics, the data lent itself to } \\
\text { a thematic analysis. Thematic analysis is inductive and } \\
\text { flexible and provides access to empirical material to } \\
\text { open the possibility for communication of ideas and } \\
\text { findings (Boyatzis, 1998). This involved a process of } \\
\text { making sense of the educator's responses around the } \\
\text { WikiRate case study. The analysis involved iteratively } \\
\text { reading, coding and categorising the material to make } \\
\text { sense of the data. As Spiggle (1994) notes, there is no } \\
\text { universal template for interpreting qualitative data. The } \\
\text { data drove the analytic process in this instance; given } \\
\text { the nature of the research, it did not make sense to } \\
\text { impose predefined categories on the data. The analysis } \\
\text { was conducted by four researchers in the following } \\
\text { way. In the first phase, the researchers independently } \\
\text { read the transcripts several times, developing initial } \\
\text { codes. At the end of the process, the researchers met } \\
\text { and compared notes. In this phase, the research team } \\
\text { began grouping, "previously identified categories into } \\
\text { more general, conceptual classes" (Spiggle, 1994, p. } \\
493 \text { ). This was made easier by the high level of inter- } \\
\text { coder agreement. In the final phase, the researchers } \\
\text { consolidated and fine-tuned the categories into the } \\
\text { findings that are presented in the next section." }\end{array}$ \\
\hline 9 & $\begin{array}{l}\text { Some justification for not } \\
\text { including student responses } \\
\text { might also be noted. }\end{array}$ & $\begin{array}{l}\text { Thank you for this suggestion. We have included the } \\
\text { following sentence at the end of the Methodology section, } \\
\text { page 6, which we hope provides sufficient justification: } \\
\text { "It is worth mentioning that this research formed part of a } \\
\text { wider project, in which students from participating } \\
\text { universities were also surveyed. While this student-facing } \\
\text { data has been published elsewhere (Author, 1; Author, 2), } \\
\text { the focus of this study was to explore educators' } \\
\text { experiences." }\end{array}$ \\
\hline 10 & $\begin{array}{l}\text { The themes presented all seem } \\
\text { relevant, but the write up } \\
\text { places a heavy emphasis on } \\
\text { extended quotations from the } \\
\text { various respondents. Some }\end{array}$ & $\begin{array}{l}\text { We thank you for pointing this out. The section has } \\
\text { undergone substantial revision and editing for clarity and } \\
\text { comprehension (see starting from page 7). }\end{array}$ \\
\hline
\end{tabular}


editing of this section may

help to make otherwise clearly

stated themes more easily

comprehensible.

\section{Reviewer 3}

\begin{tabular}{|c|c|c|}
\hline & Reviewer comment & Author response \\
\hline 12 & $\begin{array}{l}\text { Even though the authors } \\
\text { describe the participants, the } \\
\text { tool and the way they collected } \\
\text { information, they did not } \\
\text { describe the analysis of } \\
\text { information nor the application } \\
\text { of any criteria of } \\
\text { methodological rigor for } \\
\text { qualitative research. ... there is } \\
\text { no description of the } \\
\text { procedures employed to } \\
\text { analyze information. }\end{array}$ & $\begin{array}{l}\text { We apologise for the lack of detail in our original } \\
\text { manuscript. } \\
\text { In response to comments from both you and Reviewer 2, we } \\
\text { have added text about the coding process. This is located just } \\
\text { after Table } 1 \text { - see review 2, comment } 8 \text {. } \\
\text { We hope that this addresses your concerns. Although we are } \\
\text { wary of exceeding the word limit, we would be pleased to } \\
\text { provide further detail should this prove necessary. } \\
\text { In addition, we would note that we further engaged with the } \\
\text { question of methodology in a separate response to Reviewer } \\
\text { 2. We feel that our comments to them are worth repeating } \\
\text { here. } \\
\text { We do not elaborate on questions of validity and } \\
\text { generalisability in the manuscript, but we feel it appropriate } \\
\text { to make a few additional remarks here. } \\
\text { Our findings are not generalisable in the sense that sound } \\
\text { quantitative research is generalisable, and we do not seek to } \\
\text { claim generalisability; though we are of course interested in } \\
\text { relevance for practice. We certainly do not have a large } \\
\text { enough pool of participants for statistical tests (even if } \\
\text { respondents do represent } 100 \% \text { of the population under } \\
\text { investigation); moreover, the chosen method (interviews) } \\
\text { does not permit a statistical analysis. Here we draw on } \\
\text { Michael Pratt's ( } 2009, \text { p. } 859 \text { ) suggestion to "make sure your } \\
\text { chain of evidence is clear" rather than making the error or } \\
\text { seeking to quantify qualitative data (p.858) } \\
\text { We are also wary of claiming validity, as this too is more } \\
\text { associated with quantitative research methods. We are much } \\
\text { more interested in what Wood \& Kroger (2000, p.163) refer } \\
\text { to as warranting, "providing justification and grounds for } \\
\text { one's claims". We trust that our manuscript meets this test. } \\
\text { Pratt, M. G. (2009). From the editors. For the lack of a } \\
\text { boilerplate: Tips on writing up (and reviewing) } \\
\text { qualitative research. Academy of Management Journal, } \\
52(5), 856-862 . \\
\text { Wood, L. A., \& Kroger, R. O. ( } 2000 \text { ). Doing discourse } \\
\text { analysis: Methods for studying action in talk and text. } \\
\text { Thousand Oaks, CA: Sage. }\end{array}$ \\
\hline
\end{tabular}

